\title{
MENGEMBANGKAN PROGRAM LAYANAN BIMBINGAN DAN KONSELING UNTUK MENINGKATKAN TUGAS PERKEMBANGAN MAHASISWA UPI KAMPUS CIBIRU
}

\begin{abstract}
Nenden Ineu H. ${ }^{1}$
ABSTRAK

Penelitian ini dilatarbelakangi pentingnya layanan bimbingan dan konseling diberikan kepada semua peserta didik termasuk mahasiswa UPI Kampus Cibiru, dalam pemberian layanan bimbingan dan konseling tersebut perlu dipersiapkan programnya dahulu yang dilandasi pada layanan yang sangat diperlukan oleh mahasiswa, berdasarkan pengamatan awal ternyata layanan bimbingan yang sangat essensial dalam memfasilitasi dan mengembangkan tugas perkembangannya, karena menurut pendapat ahli psikologi perkembangan Havighurst jika individu mencapai tugas perkembangan yang optimal akan memperoleh kebahagiaan dan sebaliknya jika tidak mencapai tugas perkembangan yang optimal akan mendapat kesedihan dan menghambat tugas perkembangan selanjutnya. Oleh karena itu tugas perkembangan yang optimal akan berimplikasi kepada prestasi belajarnya. Metode penelitian yang dilakukan dengan deskriptif, instrumen penelitiannya I T P(Inventori Tugas Perkembangan). Hasil dan pembahasan diperoleh setelah di tes tugas-tugas perkembangan mahasiswa dengan ITP menunjukan belum mencapai tugas perkembangan pada aspek kematangan intelektual, kemandirian perilaku ekonomis, landasan perilaku etis dan kesiapan untuk menikah dan berkeluarga.Sehingga disususnlah program Bimbingan dan konseling untuk memfasilitasi meningkatkan tugas perkembangan mahasiswa, program layanan Bimbingan dan Konseling terdiri atas layanan dasar, layanan responsif, layanan perencanaan individual dan layanan dukungan sistem.
\end{abstract}

Kata Kunci : Tugas perkembangan, Program BK

\section{A. PENDAHULUAN}

Layanan Bimbingan dan Konseling sebabgai bagian dari unsur pendidikan, yang terpadu dan takterpisahkan dari keseluruhan kegiatan pendidikan hendaknya lebih memungkinkan peserta didik mengenal mengenal dan menerima dirinya sendiri dan lingkungannya secara positif dan dinamis, serta mampu memilih, mengambil keputusan, mengarahkan dan mewujudkan dirinya secara efektif dan produktif sesuai dengan tuntutan peranannya dimasa depan. Sesuai dengan peranannya Bimbingan dan Konseling upaya strategi layanan untuk mengembangkan potensi mahasiswa UPI kampus cibiru secara optimal, sebagaimana tujuan layanan bimbingan diberikan kepada peserta didik yang diungkapkan oleh Juntuka Nurihsan (2003 : 12)sebagai berikut tujuan layanan bimbingan agar individu dapat : (1) merencanakan kegiatan penyelesain studi,

\footnotetext{
${ }^{1}$ Dosen UPI Kampus Cibiru
} 
perkembangan karir serta kehidupannya dimasa yang akan datang, (2)mengembangkan seluruh potensi dan kekuatan yang dimilikinya seoptimal mungkin, (3)menyesuaikan diri dengan lingkungan pendidikan, lingkungan masyarakat serta lingkungan belajarnya, (4) Mengatasi hambatan dan kesulitan yang dihadapi dalam studi, penyesuaian dengan lingkungan pendidikan, masyarakat maupun lingkungan kerja.

Berdasarkan tujuan layanan bimbingan dan konseling tersebut di atas maka secara umumlayanannya dikaitkan dengan pengembangan sumber daya manusia agar mampu menjawab tantangan kehidupan masa depan artinya proses pendidikan bagi para mahasiswa tidak hanya dipandang sebagai proses pembelajaran yang dilengkapi dengan ekstra kurikuler belaka, tetapi disempurnakan dengan layanan bimbingan dan konseling yang membantu mempermudah mahsiswa mengenal bakat, minat dan kemampuannya serta memilih dan membuat keputusan dapat menyesuaikan diri dengan kesempatan pendidikan dan karirnya sesuai dengan tuntutan lingkungan hidupnya. Dengan demikian upaya dan strategi layanan bimbingan dan konseling di UPI Kampus Cibiru sebaiknya disesuaikan dengan karakteristik dan kebutuhan perkembangan mahasiswa serta permasalahannya yang sedang dialami secara mayoritas oleh mahasiswa UPI Kampus Cibiru.

Lazimnya kebutuhan dan permasalahan yang sering dialami oleh mahasiswa pada umumnya belum terpenuhinya mencapai tugas perkembangan, seprti yang dijelaskan oleh Robert J.Havighurst (1961) dalam Sofyan Willis (2005 : 4) tugas-tugas perkembangan yang harus diselesaikan, berhasil tidaknya individu dalam menyelesaikan tugas-tugas tersebut akan berpenharuh bagi perkembangan selanjutnya, terutama terhadap penyesuaian diri didalam masyarakat seperti masalah penyesuaian diri, masalah ekonomi dan mendapatkan pekerjaan, masalah perkawinan dan hidup berumah tangga, masalah pendiddikan, mengisi waktu luang dan kebebasan seks. Selanjutnya layanan bimbingan dan konseling UPI Kampus Cibiru terlebih dahulu perlu dikembangkan programnya dahulu yang mengacu pada pencapaian tugas perkembangan mahasiswa, yang sudah masuk kemasa dewasa muda sekitar usia 18 - 40 tahun yang harus diketahui tugas perkembangannya (diukur) dengan menggunakan ITP (Inventori Tugas Perkembangan ) yang dikembangkan oleh Prof.Dr.Sunaryo. K ,dkk. Sehingga masalahnya dapat dirumuskan sebagai berikut.

1. Apakah tugas perkembangan mahasiswa UPI Kampus Cibiru sudah mencapai perkembangan yang optimal

2. Tugas perkembangan yang bagaimana yang belum dicapai oleh mahasiswa UPI Kampus cibiru

3. Bagaimana program layanan bimbingan dan konseling yang akan dikembangkan untuk meningkatkan tugas perkembangan.

Tujuan penelitiannya adalah sebagai berikut.

1. Untuk mendapatkan gambaran ketercapaian tugas-tugas perkembangan mahasiswa UPI Kampus Cibiru 
2. Untuk mengetahui tugas perkembangan yang bagaimana yang belum dicapai oleh mahasiswa UPI Kampus Cibiru

3. Untuk mengembangkan program layanan bimbingan dan konseling di UPI Kampus Cibiru dalam meningkatkan tugas-tugas perkembangan mahasiswa yang belum dicapai secara optimal.

\section{B. PEMBAHASAN}

\section{Kajian Pustaka}

Pengertian Bimbingan menurut Donald G.Mortensen dan Alan M.Schmuller (1976) dalam Juntika Nurihsan (2003 : 10) Guidance may be defined as that part of educational program that helpes provide the personal apportunities and specialized staff services by each individual can develop to the fullest of his abilities and capasities in term of the democraties idea (Bimbingan didefinisikan merupakan bagian dari keseluruhan program pendidikan yang dapat membantu memberikan kesempatan dan secara khususnya layanan yang diberikan oleh para ahli supaya setiap individu dapat mengembangkan kemampuan dan potensinya secara penuh dalam ide demokratisnya)

Menurut Kartadinata (1998 : 3) dalam Uman Suherman (2013 : 9) menjelaskan bimbingan merupakan proses membantu individu untuk mencapai perkembangan yang optimal.

Uman Suherman (2013 : 15) berpendapat bimbingan merupakan proses bantuan kepada individu sebagai bagian dari program pendidikan yang dilakukan oleh tenaga ahli agar individu mampu memahami dan mengembangkan potensinya secara optimal sesuai dengan tuntutan lingkungannya.

Pengertian konseling, diungkapkan oleh ASCA (American School counselor Assosiation) dalam Juntika Nurihsan (2003 : 15) konseling adalah hubungan tatap muka yang bersipat rahasia, penuh dengan sikap penerimaan dan pemberian kesepakatan dari konselor kepada klien, konselor mempergunakan pengetahuan dan keterampilannya untuk membantu kliennya mengatasi masalahmasalahnya.

Definisi konseling menurut Cavanagh (1982) dalam Uman Suherman (2013 : 11) mengemukakan konseling ditujukan oleh suatu hubungan antara pemberian bantuan, bantuan yang diberikan berupa keterampilan dan penciptaan suasana yang membantu orang lain melalui cara-cara yang lebih tumbuh dan produktif.

Program Bimbingan dan Konseling : para konselor atau para pendiddik sebelum melaksanakan layanan bimbingan dan konseling kepada par kliennya atau peserta didiknya terlebih dahulu harus menyusun program layanan bimbingan dan konseling supaya dalam memberikan layanan terarah dan sistimatik. Karena programtersebut merupakan rangkaian kegiatan yang 
terencana, terorganisir dan terkoordinasi, karena itu yang dimaksud dengan program ialah suatu rangkaian kegiatan bimbingan dan konseling yang terencana, terorganisir dan terkoordinasi selama periode waktu tertentu.

Tugas perkembangan menurut Havighurst (1950) dalam Syamsu Yusuf (2000 : 65) suatu tugas yang timbul pada satu periode tertentu dalam kehidupan individu, dimana mencapai suatu keberhasilan dalam menyelesaikan tugasnya menimbulkan perasaan bahagia serta keberhasilan pada tugas berikutnya sedangkan jika individu mengalami kegagalan dalam tugas perkembangannya akan mengalami hambatan dan ketidak bahagiaan dalam menyelesaikan tugas berikutnya. Tugas perkembangan mahasiswa usia 18 - 24 tahun dalam Syamsu Yusuf (2004 : 6) yang dikemukakan oleh Sunaryo Kartadinata dkk sebagai beriku.
a. Landasan hidup religius
b. Landasan perilaku etis
c. Kematangan emosi
d. Kematangan intelektual
e. Kesadaran tanggungjawab sosial
f. Kesadaran gender
g. Mengembangkan pribadi
h. Wawasan dan kesiapan karir
i. Kematangan hubungan dengan teman sebaya
j. Kesiapan diri untuk menikah dan berkeluarga.

\section{Metode Penelitian}

Metode penelitian yang digunakan adalah metode deskriptif untuk memperoleh informasi mengenai tugas perkembangan mahasiswa UPI Kampus Ciniru, apakah sudah mencapai tugas perkembangan yang optimal, dan tidak untuk menguji hipotesis tertentu akan tetapi hanya menggunakan apa adanya tentang gejala atau keadaan yakni tugas perkembangan mahasiswa, subjek penelitiannya adalah mahasiswa PGSD dan PGPAUD semester III tingkat II tahun ajaran 2013/2014. Sedangkan teknik pengolahan data dalam penelitian ini adalah menggunakan perangkat Inventori Tugas Perkembangan (I $\mathrm{T} \quad \mathrm{P}$ ) yang dikembangkan oleh Prof.Dr.Sunaryo Kartadinata, dkk (2000 : 10)

\section{Hasil Penelitian dan Pembahasan}

Berdasarkan hasil pengukuran tugas perkembangandengan menggunakan ITP mahasiswa PGSD yang belum mencapai tugas perkembangan secara optimal yaitu (1) kematangan intelektual, (2)kemandirian perilaku ekonomis, (3) landasan perilaku etis, sedangkan mahasiswa PGPAUD tugas perkembangan yang belum mencapai optimal yaitu (1) kesiapan diri untuk menikah dan berkeluarga, (2) kemandirian perilaku ekonomis. 
Pembahasan, berdasarkan hasil pengukuran Inventori Tugas Perkembangan (I T P) tugas perkembangan mahasiswa PGSD dan PGPAUD UPI Kampus Cibiru yang belum tercapai tugas perkembangannya secara optimal dalam aspek kematangan intelektual, kesiapan untuk menikah dan berkeluarga, kemandirian perilaku ekonomis, dsn landasan perilaku etis. Oleh karena itu perlu dikembangkan melalui layanan bimbingan dan konseling sebagaimana yang di jelaskan oleh Juntika Nurihsan (2005 : 27) layanan bimbingan dan konseling dikembangkan dalam suatu program bimbingan dan konseling yang dijabarkan dalam empat kegiatan utama yaitu : 1).layanan dasar bimbingan, 2) layanan responsif, 3).layanan perencanaan individual, 4)layanan dukungan sistem.

\section{PENUTUP}

Berdasarkan hasil penelititian dan pembahasan mahasiswa UPI Kampus Cibiru program studi PGSD dan PGPAUD semester III tahun ajaran 2013/2014 setelah dialkukan pengetesan tugas perkembangannya dengan I T P (Inventori Tugas Perkembangan) hasilnya sebagai berikut.

1. Mahasiswa PGSD dan PGPAUD belum mencapai tugas perkembangan yang optimal

2. Tugas perkembangan yang belum dicapai secara optimal oleh mahasiswa PGSD : aspek intelek tual, kematangan perilaku ekonomis, dan landasan perilaku etis, sedangkan yang belum dicapai tugas perkembangan oleh mahasiswa PGPAUD adalah kesiapan diri untuk menikah dan berkeluarga, kemandirian perilaku ekonomis, dan landasan perilaku etis

3. Berdasarkan tugas-tugas perkembangan yang belum dicapai oleh mahasiswa UPI Kampus Cibiru maka program yang akan dikembangkan adalah :

Layanan dasar bimbingan, layanan responsif, layanan perencanaan individual, dan layanan dukungan sistem.

Saran layanan bimbingan dan konseling tidak hanya diberikan kepada mahsiswa bermasalah saja akan tetapi kepada semua, oleh karena itu layanan bimbingan dan konseling sebaiknya dilakukan secara periodik oleh semua dosen tidak hanya oleh dosen BK akan tetapi oleh semua dosen seperti oleh dosen PA.

Maka dari itu Program Bimbingan dan Konseling yang akan dikembangkan di UPI Kampus Cibiru adalah sebagai berikut.

\section{Layanan Dasar Bimbingan}

Layanan dasar bimbingan merupakan proses pemberian bantuan kepada semua mahasiswa (for all) melalui kegiatan-kegiatan secara klasikal atau kelompok yang disajikan secara bersamaan dengan proses pembelajaran dalam rangka membantu semua mahasiswa agar memperoleh keterampilan dasar 
hidupnya, atau dengan kata lain membantu mahasiswa agar mereka dapat mencapai tugas-tugas perkembangannya.

\section{Layanan Responsif}

Layanan responsif merupakan pemberian bantuan kepada mahasiswa yang memiliki kebutuhan dan masalah yang memerlukan pertolongan segera. Tujuan layanan adalah membantu mahasiswa agar dapat memenuhi kebutuhannya dan memecahkan masalah yang mengalami hambatan, kegagalan dalam tugas-tugas perkembangannya. Karena layanan responsif bersifat segera maka dari analisis kebutuhan dengan menggunakan Inventori Tugas Perkembangan (ITP) didapat nilai pencapaian tugas yang terendahnya adalah :

a. Kematangan Intelektual, kompetensi dari isi program layanan bimbingan dan konseling yang dapat dikembangkan dalam memfasilitasi mahasiswa untuk mencapai tugas perkembangan di atas yaitu.

1) Pada tataran pengenalan mahasiswa mempelajari cara-cara pengambilan keputusan dan pemecahan masalah berdasarkan informasi /data yang akurat.

2) Pada tataran akomodasi mahasiswa menyadari pentingnya mengkaji berbagai alternatif keputusan pemecahan masalah secara objektif.

3) Pada tataran tindakan mahasiswa mengambil keputusan dan pemecahan masalah atas dasar informasi /data secara objektif serta bermakna bagi dirinya dan orang lain. Seperti yang diungkapkan oleh Havighurst dalam hartinah Siti (2008 : 48)tugas perkembangan usia 18 - 24 tahun pada kemampuan intelektualnya mengembangkan konsep-konsep dan keterampilan intelektual untuk hidup bermasyarakat, mengembangkan konsep-konsep tentang hukum, pemerintah, ekonomi, politik, institusi sosial yang cocok bagi kehidupan modern, mengembangkan keterampilan berpikir dan berbahasa untuk dapat memecahkan problema-problema masyarakat modern.

b. Kesiapan diri untuk menikah dan berkeluarga kompetensi dan isi program layanan bimbingan dan konseling yang dapat dikembangkan dalam memfasilitasi mahasiswa untuk mencapai tugas perkembangan di atas yaitu :

1) Pada tataran pengenalan mahasiswa mengkaji secara mendalam tentang norma pernikahan dan kehidupan berkeluarga

2) Pada tataran akomodasi mahasiswa meyakini nilai-nilai yang terkandung dalam pernikahan dan berkeluarga sebagai upaya untuk menciptakan masyarakat yang bermartabat.

3) Pada tataran tindakan mahasiswa memiliki kesiapan untuk menikah atau berkeluarga dengan penuh tanggungjawab sesuai apa yang dinyatakan tugas perkembangan usia 18- 24 tahun (dewasa muda) menurut Havighurst dalam hartinah Siti (2008 : 49) memilih pasangan hidup masa dewasa muda merupakan masa awal membina karir dan berkeluarga, kehidupan keluarga diawali dengan memilih pasangan hidup sebagai suami dan istri. Pasangan suami istri selain didasari oleh ras kasih sayang juga harus didasari oleh pertimbangan yang matang tentang kesesuaian 
sifat, kesamaan tujuan hisup, serta berbagai kemampuan dan kesiapan melaksanakan tugas-tugas keluarga.

c. Kemandirian perilaku ekonomis, kompetensi dan isi program layanan bimbingan dan konseling yang dapat dikembangkan dalam memfasilitasi mahasiswa untuk mencapai tugas perkembangan di atas yaitu.

1) Pada tataran pengenalan mahasiswa memperkaya strategi dan mencapai peluang dalam berbagai tantangan krhidupsn

2) Pada tataran akomodasi mahasiswa meyakini nilai-nilai hidup hemat, ulet, sungguh-sungguh dan kompetitif sebagai aset untuk mencapai hidup mandiri dalam keragaman dan saling ketergantungan kehidupan.

3) Pada tataran tindakan mahasiswa mahasiswa memelihara dalam keragaman dan saling ketergantungan kehidupan.

Program bimbingan dan konseling untuk meningkatkan tugas perkembangan kemandirian perilaku ekonomis pada mahasiswa UPI Kampus Cibiru seperti halnya menurut ahli psikologi perkembangan Syamsu Yusuf (2000) bahwa usia mahsiswa berumur sekitar 18 tahun sampai 25 tahun mereka dapat digolongkan pada masa remaja akhir samapai masa dewasa awal, maka tugas perkembangannya menurut Havighurst dalam Hartinah Siti (2008 : 50 ) memulai kegiatan pekerjaan, pekerjaan bukan hanya berfungsi untuk mendapatkan nafkah tetapi juga merupakan bagian dari karir dan sekaligus identitas dan prestise dari keluarga seoarang dewasa muda harus menyiapkan, memilih memasuki pekerjaan yang cocok dengan kemampuan dan latar belakang pendidikannya untuk kemudian mengembangkan dirinya seoptimal mungkin dalam pekerjaan tersebut, walaupun seseorang telah mengikuti pendidikan untuk sesuatu pekerjaan dalam prakteknya masih harus banyak belajar dan mengembangkan diri.

d. Landasan perilaku etis kompetensi dan isi program bimbingan dan konseling yang dapat dukembangkan dalam memfasilitasi mahasiswa untuk mencapai tugas perkembangan di atas yaitu :

1) Pada tataran pengenalan mahasiswa menelaah lebih jauh luas tentang nilai-nilai universal dalam kehidupan manusia

2) Pada tataran akomodasi mahasiswa menghargai keyakinan nilai-nilai sendiri dalam keragaman nilai-nilai yang berlaku dimasyarakat

3) Pada tataran tindakan mahasiswa berperilaku atas dasar keputusan yang mempertimbangkan aspek-aspek nilai dan keberanian menghargai resiko dan keputusan yang diambil.

Pengembangan program bimbingan dan konseling tersebut dalam memfasilitasi mahasiswa untuk mencapai tugas perkembangan perilaku etis, sebagaimana mengacu pada tugas perkembangan masa dewasa muda oleh Havighurst dalam hartinah Siti (2008 : 50) menemukan persahabatan dalam kelompok sosial seperti kelompok etnis, agama, budaya, profesi, dan hobi seorang dewasa dituntut untuk dapat hidup dalam berbagai kelompok sosial tersebut dengan harmonis. 


\section{Layanan Perencanaan Individual}

Layanan perencanaan individual layanan ini merupakan proses bantuan yang diberikan kepada mahasiswa agar mampu merumuskan dan melakukan aktivitas yang berkaitan dengan perencanaan masa depan berdasarkan pemahaman akan kelebihan dan kekurangan dirinya, serta pemahaman akan peluang dan kesempatan yang tersedia di lingkungannya. Tujuan layanan adalah sebagai upaya memfasilitasi mahasiswa untuk merencanakan memonitor dan mengelola rencana pendidikan karir dan pengembangan pribadi sosial secara mandiri seperti yang diungkapkan oleh Gustad dalam Sukardi Dewa ketut (1988 : 12) bimbingan karir bertujuan membantu mahasiswa dengan metode yang sesuai dengan kebutuhan mahsiswa tersebut dalam kaitannya dengan keseluruhan program ketenagaan agar dapat mempelajari lebih baik tentang dirinya untuk memperoleh tujuan-tujuan hidup yang jelas, tepat dan realistis sehingga mahasiswa dapat menjadi anggota masyarakat yang berbahagia dan lebih produktif.

\section{Layanan Dukungan Sistem}

Kegiatan komponen di atas merupakan pemberian layanan bimbingan dan konseling kepada mahasiswa secara langsung layanan dukungan sistem ini meliputi dua aspek di antaranya.

a. Pemberian layanan konsultasi

1) Konsultasi dan penyelenggaraan program kerja sama dengan dosen wali/ dosen pembimbing akademik

2) Berpartisipasi dalam merencanakan kegiatan-kegiatan kampus

3) Melakukan penelitian tentang masalah-masalah yang berkaitan erat dengan bimbingan dan konseling

b. Kegiatan Manajemen

1) Pengembangan program

2) Pengembangan staf

3) Penataan sumber daya

4) Pengembangan penataan kebijakan

Layanan dukungan sistem ini mengacu kepada yang diungkapkan oleh Thomas Ellis(1990) dalam Juntika Nurihsan (2005: 35 ) dukungan sistem adalah kegiatan manajemen yang bertujuan untuk memantapkan, memelihara, dan meningkatkan program bimbingan secara menyeluruh melalui pengembangan profesional hubungan masyarakat dan staf, konsultasi dengan guru, staf ahli / penasehat masyarakat yang lebih luas manajemen program dan pengembangannya.

\section{DAFTAR PUSTAKA}

Furqon (2005) Konsep dan aplikasi Bimbingan dan Konseling di SD Bandung : Pustaka Bani Quraisy

Hartinah, Siti (2008)Pengembangan peserta didik Bandung : Refika Aditama 
Nurihsan Ahmad Juntika (2005) Strategi Layanan Bimbingan dan konseling Bandung : Refika Aditama

Nurihsan Ahmad Juntika (2003) Dasar-dasar layanan bimbingan dan konseling, BandungMutiara

Santrock.John .W(2007) Remaja Jakarta : Erlangga

Sunaryo, dkk (2000) Inventori Tugas Perkembangan Bandung : PPB UPI

Sunaryo, dkk (2000) Petunjuk Teknis ITP Mahasiswa Bandung : PPB UPI

Suherman Uman (2013) Manajemen Bimbingan dan Konseling Bandung : Rizqi Press

Willis.Sofyan.S (2005) Remaja dan Masalahnya Bandung : Alfa Beta

Yusuf Syamsu \& Nurihsan Juntika (2000) Penyusunan Program Bimbingan dan Konse Ling berbasis Perkembangan Bandung : PPB UPI

Yusuf Syamsu (2000) Psikologi pekembangan Anak dan Remaja Bandung : Remaja Rosda Karya

Yusuf Syamsu (2004) Layanan Bimbingan Dan Konseling Bagi Mahasiswa Bandung : UPT LBK 